\title{
Political Economy in a Globalized World
}

\author{
Jørgen Ørstrøm Møller, 2009 \\ Political Economy in a Globalized World. \\ World Scientific Publishing, Singapore, 464 sider
}

Jørgen Ørstrøm Møller er en energisk deltager i den globale engelsk-sprogede debat, i en sådan grad at Andrew Moravcik har kaldt ham „one of our most creative international thinkers". Nogle af de mange artikler og indlæg, publiceret overalt i verden, har han samlet og tematiseret i denne bog. De er policy-relaterede, men samtidig præget af forfatterens ukuelige nysgerrighed og ønske om at være på forkant, at kunne se om hjørner. Faktisk er bogen dedikeret til nysgerrigheden: „To 'CURIOSITY', embedded in all human beings, but all too often kept under strict guard." Efter årtier som top-diplomat er spørgelysten ikke dæmpet, men det hører med i billedet, at Ørstrøm dels har en fremtidsforsknings-side, dels har udgivet omtrent ligeså mange bøger, som karrieren har år.

Bogens fokus er økonomisk globalisering, økonomisk integration og det globale finansielle system, med en betoning af Asiens betydning for verden, og en vægt på at se kommende globale trends. De fleste artikler er fra 20068 , men undertiden gribes der længere tilbage.

Den teoretiske tilgang ekspliciteres ikke, men han kombinerer økonomens uddannelse med en stærk opmærksomhed på magtforhold og politisk kamp. Det bliver politisk økonomi, eller international politisk økonomi, og befrugtet med praktikerens mangeårige erfaring i Europa og Asien. Dertil lidt af fremtidsforskerens arbejdsmetoder koblet med megen historisk sans - og vel også en afsmitning fra de mange års diplomatiske indberetninger til Asiatisk Plads.

Hvad er det så for emner, de mange artikler drøfter? Allerførst er det forsøget på at lave en sammenhængende analyse af de emner, som vil dominere den globale dagsorden fremover. For Ørstrøm er det knapheden på vand, energi, fødevarer, råvarer og rene omgivelser. Derfor vil global politik handle om byrdefordeling, fremfor om fordelingen af fordele. Håbet om at undgå fatal konflikt, imens den globale magtbalance ændrer sig med Asiens opkomst, ligger i en stærkt nødvendig opdatering af de dårligt fungerende internationale institutioner. „The system is out of touch, does not respond to current challenges and does not incorporate a number of important players. The contrast is striking with the post-World War II system which was responsive and delivered the goods." Men også globaliseringen skal forsvares i en tid, hvor den har skabt megen ulighed uden samtidig at have tilvejebragt en global bevidsthed hos det store flertal af jordens befolkning. Dette forsvar skal ikke ske ved militær magt og „regime change" eller intervention, men dels ved fattigdomsbekæmpelse, dels ved respekt for andre og deres kultur anskuet som værdisæt. Især institutionernes betydning samt deres konflikter med nationalstaten går som en sitrende rød tråd gennem hele bogen, og det gør også spændingen mellem eliter og (tabende) masser i internationaliseringsprocessen - som i sidste ende kan styrke nationalisme og populisme. Knaphederne vil desuden gøre fattige lande endnu fattigere, og dermed vil heller ikke „vinderne“ være sikre, „for it is unlikely that the losers would leave off revolting against a world system that condemns them to seemingly eternal poverty and humiliation."

I sit vue ud over økonomisk globalisering beskæftiger Ørstrøm sig med USA's forfald, overførslen af købekraft til Asien og faren for et isolationistisk Amerika. Det er også en grund til at overveje mulighederne for at bevæge sig mod „world governance“, og de hindringer der findes for det - $\mathrm{fx}$ i form af maksimeringen af kulturelle forskelligheder som følge af immigration eller mediernes stadig mere problematiske rolle. Med koncentrationen af medieejerskab bliver man mindet om A.J. Lieblings ord: „Freedom of the press is limited to those who own one". For Ørstrøm er det „the increasingly obvious ideological alignment of major media networks with political parties", som underminerer den traditionelle rolle som forsvarer for den offentlige interesse, alt imens politik og reportage bliver umulige at skelne fra hinanden. Europæisk integration har ikke overraskende en stor plads i forfatterens hjerte, og han argumenterer indgående for EU-modellens betydning for ASEAN-landene. Men samtidig viser han i en grundig analyse, at de to egentlig aldrig har forstået hinanden.

Det meget kvalificerede afsnit om det globale finansielle system viser, at forfatteren var tidligt ude med advarsler om den kommende økonomiske krise. Dens hovedårsag var årtiers opbygning af uligevægte i amerikansk $ø$ konomi, kombineret med investeringsfondes uansvarlige og kortsigtede adfærd, og blev hjulpet af deregulering og privatisering. Nexus var højere efterspørgsel end produktion i USA. Regeringens stigende „forgældethed“, over fire gange den samlede årlige produktion, bragte Asien 
på banen som eneste kapitalrigelige sted. Løsningen må ifølge Ørstrøm blive en overførsel af værdier fra USA til Asien, samt selvfølgelig mere international regulering. Valutakurs-ændring er nytteløst, men derimod er valutasamarbejde mellem $\mathrm{fx}_{\mathrm{x}}$ asiatiske lande vigtigt under det kaos som forestår.

Det sidste tema er netop Asiens „renæssance“. Her behandles med stor autoritet emner som sikring af fortsat fred i regionen, den kinesiske model som appellerende alternativ med dens vægt på management og meritokrati frem for valg og vestligt definerede menneskerettigheder, samt USA's rolle i Asien (og her skulle man tro, at Obamas rådgivere havde læst Ørstrøm før den succesrige Asien-tur: ,the key to the future is to perceive US-China relations in the prism of Asian integration"). Det er tydeligt at forfatteren har glæde af sin mangeårige fremskudte observationspost i Singapore, udenfor den træge europæiske mainstream-diskurs.

Hvad kunne forbedre bogen? Der er en tendens til at undervurdere Japans betydning for den forestående integration i Østasien - nu hvor landet har en Asienvenlig regering. Til gengæld overvurderes efter mit skøn betydningen af en Indien-Kina akse. De har ingen strategisk konflikt og stor økonomisk komplementaritet, men mangler fælles gods. Det har Kina med ASEAN og Japan, og integrationen er allerede en del længere end europæiske observatører har indset. Derimod har USA (endnu?) ikke bevæget sig så langt mod protektionisme, som Ørstrøm har frygtet. Måske grundet G-2 samarbejdet med Kina?

Det er små indvendinger overfor den tour de force, som bogen udgør. Det er også befriende at se, hvor intenst forfatteren deltager i debatten, i nogen modsætning til vore hjemlige IP-miljøers dukken sig i forhold til varme emner. Bogen er meget læselig, i et direkte og klart sprog, og den vil være oplagt for enhver, der vil forstå, hvad der sker i den globale økonomi i disse år.

Clemens Stubbe Østergaard, Lektor, Institut for Statskundskab, Aarhus Universitet

\title{
Globaliseringens udfordringer: Politiske og administrative modeller under pres
}

\author{
Martin Marcussen og Karsten Ronit (red.), 2009 \\ Globaliseringens udfordringer: Politiske og administrative modeller under pres. \\ Hans Reitzels Forlag, 304 sider.
}

Det er en velkendt forestilling i den offentlige debat, at der findes en særlig dansk model, som har ligget til grund for den relative succes, man har haft i Danmark med at kombinere høj velstand, social lighed og miljømæssig bæredygtighed. Formålet med denne bog, som Martin Marcussen og Karsten Ronit fra Institut for Statskundskab, Københavns Universitet, har redigeret, er at komme ind bag forestillingen om en sådan samlet dansk succesmodel. De vil således kaste lys på et meget relevant emne både $\mathrm{i}$ forhold til den bredere debat, om hvilke udfordringer det danske samfund står overfor, og i forhold til den samfundsvidenskabelige debat om samspillet mellem nationale politiske og administrative modeller og så globaliseringen.

Bogen er bygget op omkring en samlet teoretisk ramme samt en række forskningsspørgsmål, der undersøges i otte sektoranalyser - skrevet af sektorspecialister - for til sidst at blive samlet op i et konkluderende kapitel. Forskningsspørgsmålene kan opsummeres i tre punkter:
1. Findes der overhovedet en samlet dansk model?

2. Hvordan påvirkes den (eller de) danske model(ler) af globaliseringen?

3. Hvor holdbare er den (eller de) danske modeller givet presset udefra?

Da svaret på spørgsmål 1 er, at der er tale om flere danske modeller, kommer spørgsmålene 2 og 3 til at handle om en flerhed af danske modeller.

Den teoretiske ramme benytter den i litteraturen velkendte sondring mellem politisk og økonomisk globalisering. Det er et velvalgt træk, da både omfanget af og udfordringen fra de to typer globalisering varierer mellem de enkelte sektorområder. Derudover indeholder rammen en kausalmodel. Globaliseringen ses som en uafhængig variabel, der påvirker holdbarheden af de danske modeller på de enkelte sektorområder. Det nærmere indhold af denne påvirkning er dog relateret til udformningen af den hidtidige model på området. Holdbarhed opfattes som et flerdimensionelt begreb, der både har en økono- 
misk, politisk, social og miljømæssig side. Det forekommer igen at være en velvalgt definition i den forstand, at den muliggør de meget nuancerede og kontekstrige empiriske analyser, der udføres i de otte sektorkapitler.

I sektorkapitlerne analyseres modellerne og deres holdbarhed givet globaliseringens udfordringer på forskellige politikområder. Man kommer igennem så forskellige områder som generel forvaltning, finansiering, arbejdsmarked, udenrigspolitik, klima, medier, fødevaresikkerhed og sundhed. De enkelte kapitler gennemgås ikke her, men to interessante kapitler skal dog nævnes. Det er for det første kapitel 2, som er skrevet af Hanne Foss Hansen og Torben Beck Jørgensen. De analyserer den danske forvaltningsmodel, og de finder - hvilket er et nyt og spændende argument - at modellen ikke blot kan forstås ved sine strukturelle og institutionelle træk, idet den også er baseret på bestemte værdier. De ser også importen af nye forvaltningspolitiske idéer som den største eksterne trussel mod den danske forvaltningsmodel. Det er dog samtidig også det element af globaliseringen, som forekommer mindst uafvendeligt. Det er for det andet kapitel 9 af Karsten Vrangbæk og Klaus Høyer. De analyserer de udfordringer, som den stigende grænseløshed på sundhedsområdet giver for den eksisterende danske sundhedsmodel. Her identificerer de blandt andet den interessante, men analytisk svært håndterbare dobbelthed, at globalisering i form af stigende udveksling over grænser skaber pres for markedsgørelse af sundhedsvæsenet, hvilket igen styrker globaliseringen.

Sektoranalyserne og en samlet afsluttende og tværgående analyse fører frem til svarene på bogens forskningsspørgsmål. En hovedkonklusion er, at der slet ikke findes en enkelt dansk model, men derimod en række sektorspecifikke modeller, der ikke kan puttes ind under en eller anden overordnet (og succesfuld) dansk model. En anden central konklusion er, at de forskellige sektormodeller er blevet påvirket af og har reageret på globaliseringen på vidt forskellige måder. Nogle har været fleksible, andre robuste og endelig nogle helt upåvirkelige. Det fører videre til den konklusion, at selvom globaliseringen samlet set har ført til en fragmentering af den politiske styring i samfundet, er det stadig sådan, at globaliseringen på nogle punkter udfordrer og på andre punkter understøtter holdbarheden af sektormodellerne. Dermed kan simple forestillinger om, at globaliseringen har en entydig og uafvendelig effekt på tværs af politikområder, afvises. Ligeledes er det også klart, at der ikke findes en samlet succesfuld dansk model, som er klar til eksport. Der er slet ikke én dansk model, ligesom de forskellige danske modeller er funderet i bestemte værdier, der ikke lige sådan lader sig eksportere.
Bogen har stået overfor to udfordringer, som det i høj grad er lykkedes at håndtere. For det første er det lykkedes redaktørerne at skabe en samlet bog, der systematisk belyser de samme spørgsmål med brug af de samme teoretiske begreber på tværs af kapitlerne. Derfor bør bogens kapitler - modsat mange antologier - ikke vurderes enkeltvist, men som en del af et samlet hele. Det er meget imponerende, særligt når det tages $\mathrm{i}$ betragtning, at bidragyderne kommer fra en række forskellige fagdiscipliner. For det andet er det en udfordring, at analyserne på hvert enkelt sektorområde principielt har skullet afklare, hvordan globaliseringen har påvirket sektormodellens holdbarhed. Kausalitet er imidlertid en forkætret størrelse, der sjældent lader sig påvise uden både gode data og design, der gør det muligt at isolere i dette tilfælde effekten af globalisering. Virkeligheden - særligt i studier af enkelte sektorer - tilbyder sjældent sådanne gode betingelser. Selvom bogen ikke har nogen generel diskussion af udfordringen, håndteres den imidlertid rigtig fornuftigt i mange af sektoranalyserne. Forfatterne afholder sig helt bevidst fra at komme med stærke udsagn om årsag og effekt. I stedet prøver de at sandsynliggøre, hvilke udfordringer globaliseringen stiller den analyserede sektormodel overfor, ligesom disse udfordringer $s \varnothing$ ges knyttet til modellens faktiske udvikling.

Bogen er derudover meget letlæst og velskrevet. Mange af kapitlerne giver også en rigtig god introduktion til de forskellige sektorområder. Desuden er bogen meget overbevisende i sin påvisning af, at globaliseringens udfordringer til (og påvirkning af) de danske modeller varierer fra sektor til sektor, og at denne variation både er relateret til globaliseringens forskellige former og forskelle mellem modellerne på sektorområderne. Ligeledes giver bogen - i forhold til de enkelte sektorområder - en række spændende, brede og mangesidede analyser af det komplekse samspil mellem globaliseringen og de danske sektormodellers holdbarhed.

Bogen giver dog også anledning til et enkelt mere kritisk spørgsmål. Det er, hvorvidt vi med denne bog egentlig kommer meget videre end det, den hidtidige forskning allerede har fundet. Det er jo ikke et nyt resultat, at globaliseringen ikke er en homogen størrelse, der har en entydig effekt på tværs sektorer. Det påviste bogens redaktører også i den bog om emnet, som de redigerede for Magtudredningen tilbage i 2003 (Internationaliseringen af den offentlige forvaltning $i$ Danmark). Det er også påvist i andre sammenhænge og i forhold til andre lande. Bogen ville således have kunnet levere et stærkere bidrag til den samfundsvidenskabelige viden på området, hvis den havde taget den eksisterende viden lidt mere i hånden og mere systematisk havde forholdt sig til, hvorfor vi ser varierende reaktionsmønstre på forskellige 
områder. Der er masser af empirisk substans i bogen, der kunne ligge til grund for en sådan øvelse. Et godt sted at begynde kunne have været de to hypoteser, som de to redaktører opstillede ved afslutningen af deres bog for Magtudredningen. De handlede nemlig om, hvorfor og hvornår man vil se en forskellig tilpasning til presset fra globaliseringen mellem sektorer.
Samlet set er der således tale om en meget relevant og velskrevet bog, der klart kan anbefales til alle med interesse for samspillet mellem globalisering og national politik og forvaltning. Men det er dog ikke en bog, der flytter vores viden om dette emne afgørende fremad.

Mads Leth Felsager Jacobsen, ph.d., adjunkt, Institut for Statskundskab, Aarhus Universitet

\title{
The Message Matters
}

\author{
Lynn Vavreck, 2009 The Message Matters: The Economy and Presidential Campaigns. \\ Princeton University Press, Princeton, 197 sider.
}

Lynn Vavrecks valgkamps-teori er simpel. Lidt for simpel. Men tankevækkende.

Økonomien bestemmer udfaldet af amerikanske præsidentvalg. Hvis økonomien er god, beholder det siddende parti magten. Hvis økonomien er dårlig, skifter Det Hvide Hus beboere. Altså med mindre en kandidat med økonomien imod sig siger noget intelligent under valgkampen og vælger det rigtige tema.

Vavreck, en ung amerikanske politolog fra UCLA, lægger i The Message Matters - The Economy and Presidential Elections ud med en historiografisk gennemgang af de mest markante valgkampsstudier gennem de seneste 65 år. Herigennem påviser Vavreck en udvikling inden for valgforskningen med stor fokus på økonomiens betydning, og meget lidt fokus på selve valgtemaernes betydning. Det er her, at Vavrecks bidrag skal findes. I sjældne tilfælde lykkedes det nemlig kandidater med økonomien i ryggen at tabe præsidentvalg alligevel. Richard Nixons nederlag til John Kennedy i 1960, Hubert Humphreys nederlag til Richard Nixon i 1968, Gerald Fords nederlag til Jimmy Carter i 1976 og Al Gores nederlag til George W. Bush i 2000 er, ifølge Vavreck, alle eksempler på vigtigheden af valgkampene.

Det rette valgtema fra en økonomisk udfordret kandidat kan være med til at udligne modstanderens naturlige fordel på økonomi-temaet. I stedet for at fokusere på en gunstig økonomi under republikansk ledelse valgte Nixon i 1960 at gøre udenrigspolitik til sit vigtigste valgtema. Det åbnede muligheden for Kennedy til at tale om hjemligt forfald inden for skolevæsenet, boligmarkedet, velfærden og rumprogrammet. Kennedys fokus på indenrigspolitiske problemer under den seneste republikanske regering var, ifølge Vavreck, nøglen til sejr. Vavreck demonstrerer nemlig overbevisende, at samme evne til at vælge det rigtige ikke-økonomiske tema gjorde sig gældende for både Nixon, Carter og Bush.

Med udgangspunkt i Anthony Downs' „spatial voter model“ og en større indholdsanalyse (med overbevisende interkoder-reliabilitet) sammenholdt med interviews foretaget af American National Election Study fastslår Vavreck 15 præsidentvalgs overordnede tema. Før Vavreck når så langt har hun dog tygget sig igennem 895 valg-reklamer, 2517 valgtaler og 956 New York Times valgartikler. Den undersøgelse kommer der til gengæld flere interessante resultater ud af.

For det første viser det sig, at forudsigelser omkring udfaldet af præsidentvalg bliver langt mere præcise, når økonomiske modeller også tager kandidaternes valgtema med som en variabel. For det andet påviser Vavreck overbevisende, at New York Times er mere fokuseret på at vinkle artikler dramatisk end på, hvad kandidaterne prøver at fortælle vælgerne. Denne konklusion fører til en tredje væsentlig pointe. Nemlig at vælgerne får mere at vide om kandidaternes standpunkter gennem tv-reklamer end de gør gennem medierne eller kandidaternes taler.

På bogens 166 sider bliver der dog holdt så skarpt fokus på teoretisk fundament, indholdsanalyse og ANESinterviews, at læseren bliver efterladt med flere „hvad nu hvis“ spørgsmål. Det mest åbenlyse spørgsmål går på hvorfor Vavreck i kun ét tilfælde beskæftiger sig med „third-party"-kandidater, som en delvis forklarende årsag til valgudfald. I Vavrecks optik hænger stort set alt sammen med økonomi og valgtemaer, mens Ross Perots 19 \% af stemmerne i 1992 bliver forbigået i tavshed. Samme skæbne overgår John B. Andersons kandidatur i 1980 og Ralph Naders potentielle indflydelse på 2000-valget.

I forlængelse af Vavrecks alt-eller-intet fokus på økonomi og valgtemaer er det også relevant at spørge hvor be- 
vidste kandidaterne er om den valg-typologi som Vavreck propper ned over hovedet på dem. Vavreck skriver på et tidspunkt, „Candidates seem to understand“ og „Clinton and Carville probably knew this,"(hhv. side 113 og 134), men hun argumenterer ikke for at kandidaterne rent faktisk forstår valgtemaernes betydning i forhold til økonomien og modstandernes svage punkter. Det faktum at 11 ud af 15 undersøgte kandidater med økonomien imod sig tabte, indikerer enten, at økonomien er den nærmest altafgørende faktor, eller at kandidaterne ikke ved, hvilket valgtema de skal vælge for at være konkurrencedygtige i $ø$ konomisk modvind. En analyse af kandidaternes breve, dagbøger, erindringer eller personlige interviews kunne have kastet mere lys over den del af undersøgelsen.

Som læser er man også nødt til at spørge sig selv, om Vavrecks kobling mellem New York Times' første sektion og vælgernes holdninger til kandidater er gyldig? Det ser ud til, at der er mindst tre problemer med denne kobling. For det første at New York Times bliver stedfortræder for alle amerikanske medier i analysen. For det andet at alle undersøgte vælgere dermed antages at læse New York Times, når deres holdninger bruges i analysen. For det tredje at der fra Vavrecks side bliver lagt enorm vægt på tv-reklamer som en forklarende årsag til vælgernes politiske holdninger, men på intet tidspunkt indgår der en analyse af de tv-nyheder som reklamerne ofte ligger i forlængelse af.
Slutteligt i en tid hvor der er stor fokus på komparative medie- og valgstudier, er det interessant, at Vavrecks analyse skriver sig ind i en lang tradition af etnocentriske mediestudier, og dermed får vi i Vavrecks bog aldrig svaret på om hendes teori er gyldig uden for USA's grænser. Disse fire punker skal dog ikke overskygge det faktum, at Vavrecks bog er et interessant og læseværdigt bidrag for folk med interesse i medie- og valgforskning. Hvad kandidaterne rent faktisk taler om under amerikanske valgkampe er med Vavrecks studie nu langt bedre belyst, og samtidig er der åbnet op for et væld af spændende analyser i forlængelse af The Message Matters.

Bogen er yderst velskrevet og så pædagogisk som en fortælling baseret på indholds- og regressionsanalyse nu en gang kan være. Men selv om Vavreck slutter sin bog med konklusionen, „The economy is the backdrop in front of which the great play of modern presidential campaigns is performed. The scenery is important. But as Shakespeare said, 'the play's the thing', så er man alligevel ikke helt overbevist om, at valgkampes udfald kan forklares så simpelt.

Anders B. Rasmussen, Ph.D.-studerende, Center for Journalistik, Syddansk Universitet. 